\title{
Varieties of opposition to the EU in the Low Countries
}

Citation for published version (APA):

Bijsmans, P. (2017). Varieties of opposition to the EU in the Low Countries: A comparison of the Dutch and Flemish press. In N. Startin, S. Usherwood, \& B. Leruth (Eds.), The Routledge handbook of Euroscepticism (pp. 357-368). Routledge/Taylor \& Francis Group.

https://doi.org/10.4324/9781315464015-32

Document status and date:

Published: 01/01/2017

DOI:

10.4324/9781315464015-32

Document Version:

Publisher's PDF, also known as Version of record

Document license:

Taverne

Please check the document version of this publication:

- A submitted manuscript is the version of the article upon submission and before peer-review. There can be important differences between the submitted version and the official published version of record.

People interested in the research are advised to contact the author for the final version of the publication, or visit the DOI to the publisher's website.

- The final author version and the galley proof are versions of the publication after peer review.

- The final published version features the final layout of the paper including the volume, issue and page numbers.

Link to publication

\footnotetext{
General rights rights.

- You may freely distribute the URL identifying the publication in the public portal. please follow below link for the End User Agreement:

www.umlib.nl/taverne-license

Take down policy

If you believe that this document breaches copyright please contact us at:

repository@maastrichtuniversity.nl

providing details and we will investigate your claim.
}

Copyright and moral rights for the publications made accessible in the public portal are retained by the authors and/or other copyright owners and it is a condition of accessing publications that users recognise and abide by the legal requirements associated with these

- Users may download and print one copy of any publication from the public portal for the purpose of private study or research.

- You may not further distribute the material or use it for any profit-making activity or commercial gain

If the publication is distributed under the terms of Article $25 \mathrm{fa}$ of the Dutch Copyright Act, indicated by the "Taverne" license above, 


\title{
28 \\ VARIETIES OF OPPOSITION TO THE EU IN THE LOW COUNTRIES A comparison of the Dutch and Flemish press
}

\author{
Patrick Bijsmans
}

Euroscepticism, often described as opposition to the European Union (EU), is widely believed to have gained ground in contemporary Europe. The Maastricht Treaty is often seen as the main turning point in this respect (for example Usherwood and Startin 2013: 3-4). As the chapters in this Handbook show, criticism towards the EU has been further fuelled since then, by events and crises, as well as by the rise of populist parties across Member States. Hence, some scholars have claimed that further politicization of European affairs cannot be stopped (de Wilde and Zürn 2012). The 2016 Brexit referendum has so far been the most influential manifestation of this development.

Much scholarly work has been done on trying to unpack the concept 'Euroscepticism' (see Guerra forthcoming 2017). Even so, it remains a term that is often used without clear explanation, both in and outside academia. Moreover, work in the field of Euroscepticism has mostly concentrated on the criticism and opposition raised by political parties and public opinion, yet the aforementioned developments warrant a more encompassing approach (Usherwood and Startin 2013; Vasilopoulou 2013). Little is known, for instance, about how Euroscepticism is represented in the media, despite the fact that media are crucial for acquiring and exchanging information and opinions in contemporary democratic societies - both as passive transmitters and active contributors to public debates.

This chapter addresses the topic of media and Euroscepticism by examining how different forms of scepticism and opposition to the EU feature in Dutch and Flemish newspapers. Euroscepticism may have become more prominent, even in countries that were originally seen as pro-integrationist, but this is not the case in all Member States. As such, despite there being many similarities between Belgium and the Netherlands - and Flanders and the Netherlands in particular - criticism towards European integration is less prominent in Belgium than it in the Netherlands (Abts et al. 2008: 357).

Taking into account that events are often important for EU media coverage (Boomgaarden et al. 2010) and may offer opportunities for the mobilization of Euroscepticism (Usherwood 2017), this chapter specifically looks at how varieties of Euroscepticism and opposition to the EU were represented in Dutch and Flemish mediated debates at the time of the 2014 European elections. The chapter starts with a short introduction of the topic of media and Euroscepticism. This is followed by an overview of the Dutch and Flemish stances towards the EU. Subsequently, the research design is presented, followed by the empirical findings. The chapter ends with a discussion that links these findings to the topic of media and Euroscepticism. 


\section{EU media coverage and Euroscepticism}

Generally, scholarly attention for mass media reporting about European affairs has increased. This research particularly looks into how national media cover EU affairs, as it is widely acknowledged that national media will constitute the main platforms for a European public sphere (see Risse 2010: 109-113). Studies have suggested that mass media coverage of EU affairs in national media has increased, especially at times of important events and when European policies are considered to be controversial at the national level. Hence, the increased visibility of the EU in national media has not been an even development, there being differences between countries, policy fields and institutions (for example Seifert 2006; Sifft et al. 2007).

Coverage of the European Parliament (EP) is a good example. Elections are key events in democratic polities, also in the EU, with the European elections being the most direct opportunity for citizens to influence European affairs. Additionally, the EP has been accredited for stimulating openness about European affairs (Liebert 2007). Despite this, the Parliament is less prominent in news coverage than other EU institutions (for example Trenz 2004). Coverage of European elections itself is influenced by the second-order nature of these elections, with national politicians often running on a mostly national ticket in elections that offer citizens the opportunity to have an additional say on national politics (Kevin 2003). For example, in their analysis of the news coverage of the 1999 and 2004 EP elections, Claes de Vreese et al. (2006) found that in both cases domestic political actors were more visible than EU actors.

It has, more generally, been argued that the way in which EU affairs are covered is problematic, with the focus on national perspectives and the misrepresentation of policymaking often identified as important shortcomings (for example Sifft et al. 2007). In fact, Leconte (2010; see also Anderson 2004: 170) argues that such apparent deficiencies in media reporting may stimulate the advance of Euroscepticism. Yet, this conclusion seems to be a bit too crude, because, as Vasilopoulou (2013: 157) writes, 'we still have not established the precise link between media, on the one hand, and opposition to European integration, on the other'.

There are some studies that have focused in more detail on EU media coverage and Euroscepticism. Yet, the body of work that specifically deals with this issue is still relatively small, certainly when taking into consideration the substantial amount of work on media coverage of EU affairs in general terms (see Caiani and Guerra 2017). Moreover, existing studies often take a different approach to media and Euroscepticism. Some have looked into the extent to which media are Eurosceptic, an issue that has been especially salient within the United Kingdom (UK) (for instance Daddow 2012; Startin 2015). Others have examined the effects of media coverage on opinions about the EU, in general, and the spread of Euroscepticism, in particular (for instance de Vreese 2007; Adam 2009). Media have also been used as a source for exploring other aspects of Euroscepticism, such as party competition (Statham et al. 2010). Finally, the stereotypical media coverage (for instance Touri and Rogers 2013) of certain countries could, arguably, also be looked at from the perspective of Euroscepticism.

These studies - and some that do not specifically refer to Euroscepticism (for example de Vreese et al. 2006) - often resolve around the question of whether news media coverage of EU affairs is predominantly negative or positive. This chapter moves beyond this negative/positive dichotomy. After all, studies that have looked into other aspects of Euroscepticism have argued that it comes in many different forms and is not constrained to just a pro/con distinction (Kopecký and Mudde 2002; Krouwel and Abts 2007; Crespy and Verschueren 2009).

Few media studies have so far worked along similar lines. In his analysis of Austrian Euroscepticism, Karner (2013) argues, among other things, that Austrian quality media include 
alternative evaluation of European affairs. Based on a claim-making analysis of political party positions as covered by the media, Statham et al. (2010: 271) argue that criticism mostly concerned 'the substance of Europe'. That is, certain aspects of the EU and its policies were criticized and sometimes alternatives were put forward, but integration as such was not questioned. Other scholars have therefore proposed to design new typologies. For instance, de Wilde et al. (2013) distinguish between six possible positions towards European integration, taking into account opinions for and against. Similarly, Startin (2015: 321) proposes to distinguish between 'Euro-positive', 'Eurosceptic' and 'Euro-ambivalent' newspapers.

\section{Dutch and Belgian perspectives on the EU}

Belgium and the Netherlands are similar on many counts and Flanders and the Netherlands, in particular, share a largely common language and history. Coalitions, consensus politics and corporatist arrangements have played an important role in both (Lijphart 1999). In addition, their media systems have been characterized by a tradition of political parallelism, limited state power, mass circulation of the press and journalistic professionalism (Hallin and Mancini 2004).

Despite these similarities, approaches towards European integration steadily started to diverge. Both countries were initially wary about the integration process and afraid of a dominance of France and Germany. Supranationalism only gradually came to be seen as a bulwark against this perceived dominance (Nasra and Seegers 2011). However, since the 1990s national interests have gained prominence in the Dutch political debate. The Dutch position vis-à-vis European integration has been very much affected by what has become known as 'Black Monday' (30 September 1991), when a far-reaching proposal for a new treaty on European Union was rejected by all Member States except Belgium. Consecutive Dutch governments have grown more hesitant towards further integration (Schout and Rood 2013). The 2005 referendum on the European Constitutional Treaty (ECT) firmly placed Eurosceptic arguments at the centre of public debates about the EU (van Holsteyn and Vollaard 2015).

In Belgium support for further integration remains considerable, including a certain caution towards further enlargement, which might go at the expense of further integration. In fact, Deschouwer and van Assche (2008: 92) write that the general stance of Belgian political parties is that 'the integration process is too slow, that member states retain too much power.' This has also been the case for Flemish political parties, which, despite debates about disintegration of the Belgian federal state, have mostly supported European integration (Rood and Vos 2011: 261). Where Dutch populists - Geert Wilders in particular - have been effectively venting Eurosceptic positions, Flemish populists have so far been much less successful.

In fact, European integration has only recently become more prominent in public debates in the Low Countries (Beyers et al. 2015: 11-12). As is the case in many other Member States, Dutch and Flemish media focus primarily on prominent events, important decisions and conflicts in EU affairs (van Cauwenberge et al. 2009: 207). It has been argued that Dutch media pay less attention to European affairs than media in other Member States (de Beus and Mak 2009), yet there is little research that specifically compares both cases. A recent study on the Eurozone crisis by Joris et al. (2014) has suggested that Flemish newspapers devote more attention to the EU than Dutch newspapers, with quality newspapers publishing more articles than popular titles. Yet, the frames used by the studied newspapers were largely similar. However, research on the press coverage of the Lisbon Treaty by van Cauwenberge et al. 


\section{Patrick Bijsmans}

(2009) suggests slightly more attention in the Dutch press, but also more nationalized coverage, despite the use of similar frames. Different findings like these are not necessarily a surprise, because, as already mentioned, coverage may vary across countries and cases. Yet, they do stress the need for gathering additional insights.

The fact that support for European integration tends to be a more consensual issue in Belgium than in the Netherlands is also reflected during the time of European elections. Media coverage of these elections has been limited in both the Dutch and the Flemish press (de Vreese et al. 2006; Schuck et al. 2011). In Belgium EU integration was less contested in the run up to the 2009 elections than it was in the Netherlands (de Wilde et al. 2013). The elections in Belgium coincided with regional elections. As a result, the latter dominated media coverage, despite prominent politicians such as Jean-Luc Dehaene and Guy Verhofstadt leading the lists of respectively the Flemish Christian Democrats and the Liberals (Justaert 2010). The one theme that did get some attention was the rise of Eurosceptic parties in other countries, while criticism raised by Belgian parties was mostly limited to proposing alternatives rather than outright rejection of the EU (Crespy 2011).

There were no high profile Dutch candidates for the 2009 European elections, but there was more extensive media coverage. De Wilde et al. (2013: 139) argue that this increased attention for the EP elections was due to the aforementioned referendum on the ECT, which has been 'the single most important event in recent history shaping Dutch public opinion, public discourse and party contestation concerning European integration'. The debate itself was not so much about substantive issues, but rather about being for or against the EU (Sprokkereef 2010) and about 'the perceived European threat to the Netherlands' (Vollaard 2011: 97).

\section{Research design}

To gain a better understanding of the topic of media and Euroscepticism, this chapter conducts a qualitative content analysis of the coverage of the 2014 European elections in Dutch and Flemish newspapers. For each country, one leading quality newspaper and one popular title have been selected: respectively De Standaard and Het Laatste Nieuws (Flanders) and NRC Handelsblad and De Telegraaf (the Netherlands). ${ }^{1}$

The elections took place on 22 May in the Netherlands and 25 May in Belgium. The analysis focuses on the week before the elections, the actual elections, and their immediate aftermath, that is the period from Thursday 15 May until Wednesday 28 May. Articles have been retrieved using LexisNexis for the Dutch newspapers and Mediargus for the Flemish ones, with a specific focus on news, background and analysis, as well as columns, opinion articles, readers' letters and editorials. Articles that appeared in regional editions were excluded, as were articles that were not linked with the elections.

The approach of claim-making analysis served as a basis for the empirical work, with individual statements that occur in the context of the selected articles forming the unit of analysis. More specifically, the focus was on who claimed what and on determining the assessment of EU affairs put forward by means of those claims (see also Statham et al. 2010; de Wilde et al. 2013). Here, such evaluative statements may concern both polity and policies, and can be expressed by (representatives of) citizens, media and political actors at all levels. The focus was on sceptical and oppositional statements, as well as positive and supportive statements uttered by EU and non-EU based actors (including political actors, citizens and journalists) in articles that only discussed the EP elections, as well as articles that discussed other issues, but that included claims related to the elections. 
In terms of conceptual approach, the influential distinction between 'soft' and 'hard' Euroscepticism (for example Taggart and Szczerbiak 2008) is considered to be offering too little scope for researching media representation of opinions about the EU and its policies. At the same time, while more extensive conceptualizations have proposed multiple forms of opposition and scepticism (for example Kopecký and Mudde 2002; Krouwel and Abts 2007), they are considered to be problematic to operationalize and categorize (see also Vasilopoulou 2013: 156). This also applies to the aforementioned typology designed by de Wilde et al. (2013), which, moreover, only deals with European integration in general terms, not with policies. Likewise, the typology used by Startin (2015) is useful for analysing generic media positions towards the EU, but is less suitable for analysing specific positions taken up by a variety of actors in mediated debates.

Instead, this chapter will distinguish between Euroscepticism and what FitzGibbon (2013) has called 'Euroalternativism'. The latter is an expression of 'pro-system opposition', implying that actors support the EU and European integration, but are critical towards (elements of) policies that are being pursued, often presenting alternatives or demanding further integration. In addition, pro-European opinions are included too, thus acknowledging that opinions for and against the EU and European integration are two sides of the same coin.

Hence, four possible positions can be identified: support for the EU and its policies, Euroalternativism, soft Euroscepticism and hard Euroscepticism. Combining insights from some of the aforementioned works, the first three of these have been slightly adapted and further broken down into two sub-categories as follows.

1 positions concerning the idea of European integration, including institutional design, EU membership and core elements of the EU (such as the Euro); and

2 policy fields and policy choices, including, for instance, choices related to stricter budget norms vs. more spending (that is, related to the Euro).

Taken together, this results in the positions listed in Table 28.1 (cf. Bijsmans 2017a; Bijsmans forthcoming 2017b).

Table 28.1 Possible positions on European integration and EU policies

\begin{tabular}{|c|c|c|}
\hline Position $>$ Aimed at & (1) Polity & (2) Policy \\
\hline Support & $\begin{array}{l}\text { Support for European integration and } \\
\text { the existing institutional design }\end{array}$ & $\begin{array}{l}\text { Support for the policies currently } \\
\text { being pursued }\end{array}$ \\
\hline Euroalternativism & $\begin{array}{l}\text { Support for European integration, but } \\
\text { arguing for a more supranational } \\
\text { institutional design }\end{array}$ & $\begin{array}{l}\text { Support for EU involvement in a } \\
\text { new policy or arguing for a different } \\
\text { approach in an existing policy field }\end{array}$ \\
\hline Soft Euroscepticism & $\begin{array}{l}\text { Support for a form of European } \\
\text { integration, but arguing for a more } \\
\text { intergovernmental institutional design }\end{array}$ & $\begin{array}{l}\text { Opposition to EU involvement in a } \\
\text { policy field or to a specific EU policy }\end{array}$ \\
\hline Hard Euroscepticism & \multicolumn{2}{|c|}{ Principled opposition to integration and aiming for withdrawal from the EU^ } \\
\hline
\end{tabular}

Note: ${ }^{\star}$ Here there is no distinction between claims aimed at polity or policy, as actors argue against the EU in all its facets. 


\section{Findings}

Claims were based on a total of 280 articles: 75 from De Standaard, 21 from Het Laatste Nieuws, 93 from NRC Handelsblad and 91 from De Telegraaf. As this chapter specifically focuses on statements issued in the context of the EP elections, other EU news coverage was neglected. This included, for instance, coverage of new legislation regarding due dates on food (HLN 21.05; TEL 20.05) ${ }^{2}$ and a ruling of the European Court of Justice on Google and the 'right to be forgotten' (DS 17.05; NRC 15.05). Excluded also were articles that referred to background, opinion polls, procedures and results, but without including statements related to the EU, such as, respectively, on the increasing role played by the Front National in French politics (TEL 27.05), undecided voters (HLN 17.05), Estonian e-voting (NRC 16.05) and the election of seven Commissioners from the outgoing European Commission (DS 28.05).

The European elections in Belgium took place on the same day as regional and federal elections. In addition, former Belgian prime minister, MEP and vice-chair of the convention that had drafted the defunct Constitutional Treaty, Jean-Luc Dehaene, died in the week before the elections. Articles about both events contained references to the 2014 European elections, yet often without claims related to these elections. This is predominantly illustrated by the limited number of articles and claims from Het Laatste Nieuws; initial selection yielded over 200 articles, most of which only included opinions polls or results, or did not concern themselves with the European elections at all.

Coverage by the two quality newspapers mostly included claims by established political actors (political parties, institutions, governments and individual politicians), representing over three-quarters of the total number of claims coded in these newspapers. The two popular titles provided a somewhat different take on the debate, by including claims put forward by nonestablished actors. Het Laatste Nieuws provided a stage in the debate for talented female politicians (HLN 17.05) and for younger voices - children with an interest in politics (HLN 22.05); both articles did not only discuss the European elections, but also those at regional and federal level. De Telegraaf included many citizen voices (85 out of a total of 281 claims), which generally featured in letters to the editors and polls amongst its readership (for example TEL 22.05). Often these readers were critical about the EU, sometimes refuting European integration altogether, but also at times issuing a more nuanced criticism:

I do not want to vote for a bunch of megalomaniacal politicians who invite ever more countries to join the EU, apparently unaware of the fact that the European house is already showing cracks. That is why, today, I have thrown away my voting pass. Because I am in favour of Europe. But against 'Brussels'.

(TEL 17.05)

De Standaard included quite a number of claims from the so-called 'Spitzenkandidaten' (the lead candidates for the various political groupings in the European Parliament elections), whereas the three other newspapers mostly focused on the institutional fight between the EP and the European leaders on what this novelty should mean for the appointment of the new Commission President (for example HLN 27.05; NRC 28.05; TEL 27.05). Claims often concerned future economic and monetary policy, with Alexis Tsipras, 'Spitzenkandidat' of the radical left, being the most vocal protagonist for change. De Standaard (23.05) even called him the 'hero' of the radical left.

998 claims were coded and analysed, with Table 28.2 presenting an overview of the way in which the EU and its policies were evaluated. NRC Handelsblad contained the highest absolute 
number of claims, but also the highest number of average claims per selected article: 4.15 as compared to 3.65 in De Standaard, 3.09 in De Telegraaf and 2.71 claims in Het Laatste Nieuws. This is in line with De Standaard and NRC Handelsblad being leading national media and important platforms for national debates in, respectively, Flanders and the Netherlands.

Many articles in NRC Handelsblad addressed the elections and rising criticism in particular, including inventories of parties that were identified as being 'anti-European' (for example NRC 24.05). These were often indirect claims. In fact, all newspapers tended to reserve more direct claims for articles about the expected win of the Front National (FN) of Marine Le Pen in France and Nigel Farage's UK Independence Party (UKIP) in Britain. This was combined with references to attempts by Le Pen and Dutch populist politician Geert Wilders to join forces and create a new Eurosceptic party group in the EP.

Based on Table 28.2, two general observations can be made. First, the theme 'more, or less EU?' dominated the debate, revolving around questions concerning European integration, the institutional design of the EU and justifications for the Euro and Schengen, and not so much about policies and policy options. In Het Laatste Nieuws 68 per cent of all claims concerned European integration and the like, in De Standaard 72 per cent, in NRC Handelsblad 80 per cent and in De Telegraaf no less than 82 per cent. Second, many Eurosceptic claims were found, in particular statements that rejected integration together (often combined with a call to leave the EU). In all four newspapers over half of the claims concerned arguments for or against European integration or EU policies. In both Dutch newspapers just over half of the coded claims were of a Eurosceptic nature. Such claims amounted to 44 per cent in De Standaard and 37 per cent in Het Laatste Nieuws. Due to the relatively limited number of claims coded for the lastmentioned newspaper, we should treat this number with some care.

The high number of Eurosceptic claims in De Standaard suggests that criticism and scepticism towards the EU and its policies has also become more prominent in the Flemish public sphere. However, there seems to have been an important difference between the Flemish and the Dutch debates. While there was ample attention for the general trend towards increased scepticism across the EU, the national debate in the Netherlands was an important issue in the Dutch newspapers. The predicted success of Geert Wilders' Partij voor de Vrijheid (PVV: Party for Freedom) was addressed regularly, including references to the 'horse-race' between the antiEuropean PVV and the pro-European Democraten 66 (D66; Democrats 66). More than half of

Table 28.2 Distribution of claims on European integration and EU policies

\begin{tabular}{|c|c|c|c|c|c|}
\hline & $D S$ & $H L N$ & $N R C$ & TEL & Total \\
\hline Support I & 47 & 11 & 81 & 63 & 202 \\
\hline Support II & 9 & 0 & 6 & 11 & 26 \\
\hline Euroalternativism I & 43 & 9 & 56 & 39 & 147 \\
\hline Euroalternativism II & 55 & 16 & 49 & 26 & 146 \\
\hline Soft Euroscepticism I & 20 & 2 & 50 & 44 & 116 \\
\hline Soft Euroscepticism II & 14 & 2 & 22 & 13 & 51 \\
\hline Hard Euroscepticism & 86 & 17 & 122 & 85 & 310 \\
\hline Total & 274 & 57 & 386 & 281 & 998 \\
\hline
\end{tabular}


the Eurosceptic claims in De Telegraaf were raised by national voices - citizens, politicians or others. This applied to nearly 4 out of every 10 Eurosceptic claims in NRC Handelsblad. The two newspapers themselves recalled that the debate was mostly a debate about 'more, or less' Europe (for example TEL 22.05), with NRC Handelsblad (17.05) arguing that 'a wholehearted choice for Europe does by no means exclude a critical approach towards the EU'. Columns and editorials in De Telegraaf were often more outspoken in their criticism (for example TEL 15.05).

Rising Euroscepticism was also addressed in the Flemish newspapers. Yet, only five of the 120 Eurosceptic claims in De Standaard and two of the 21 in Het Laatste Nieuws were raised by national voices, implying that the Flemish newspapers mostly only observed what was happening outside Belgium. The once influential Vlaams Belang (VB: Flemish Interest) was identified as the only party that campaigned on a truly Eurosceptic ticket, calling for a 'Vlexit' - for 'Vlaanderen' (Flanders) leaving the EU (DS 15.05). The Nieuwe Vlaamse Alliantie (N-VA: New Flemish Alliance) emphasized, in the words of its leading European politician Johan van Overtveldt, that it was in favour of a 'clear Flemish voice in a strong Europe', but a Europe that needed to be improved (HLN 24.05). The other parties also emphasized the importance of the EU, even though reforms may be needed, or even called for a federal EU. Guy Verhofstadt, European leader of the Flemish liberal party Open VLD (Open Vlaamse Liberalen en Democraten) and 'Spitzenkandidat' for the liberals in the EP, was seen as being especially keen on more integration (DS 16.05; HLN 24.05).

The Flemish newspapers also referred to the debate in the Netherlands, which was even dubbed one of the most - if not the most - 'EU-critical' countries in Europe (DS 20.05). The Dutch newspapers, for their part, hardly referred to European election debates in Belgium during the two weeks that were analysed. They did mention Dehaene's death and the cooccurrence of regional, federal and European elections, but without claims regarding the latter. In fact, writing in De Standaard (24.05), the Belgian editor-in-chief of NRC Handelsblad, Peter Vandermeersch, noted that there was relatively little attention for Belgian debates across all the main Dutch newspapers. Guy Verhofstadt did make an appearance, though mostly in the guise of the pro-European 'Spitzenkandidat' of the liberals in the EP. After the first Dutch election exit polls were published Verhofstadt tweeted that 'the Netherlands have voted in favour of Europe' (NRC 23.05). In De Telegraaf Verhofstadt was called a 'Euro-loony' ('Eurogekkie') who was imposing Europe on Belgian citizens (TEL 24.05).

The expected success of Eurosceptic parties across the continent was discussed in all four newspapers. Marine Le Pen's FN was expected to not only play an important role in French politics, but also in European politics. In collaboration with Wilders she was hoping to establish a new Eurosceptic party group in the EP, together with other parties including the Flemish VB (DS 28.05). Le Pen proclaimed that her party's win constituted a 'massive rejection of the European Union' (TEL 26.05). Her success resulted in former President Nicolas Sarkozy calling for a radical reform of the Schengen agreement (NRC 24.05), and current President François Hollande concluding that the EU had become 'incomprehensible, distant and elusive' (HLN 28.05).

The situation in the UK was also closely monitored, with Nigel Farage's expected win being seen as another step towards a possible 'Brexit' referendum (NRC 26.05). UKIP did not want to cooperate with Le Pen due to the FN's anti-Semitic past, which was seen as a complication for Le Pen and Wilder's goal to set up a new Eurosceptic group (TEL 26.05). Prime Minister David Cameron's spokesperson said that the results of the elections 'have highlighted the need for reforms' (DS 28.05). Meanwhile, Farage himself was in favour of Socialist 'Spitzenkandidat' Martin Schulz becoming the next Commission President: 'I want Schulz, of course. He's very unpleasant and aggressive. We need the worst candidate for our good cause. With Schulz as Commission President we will head straight for the end of Europe' (HLN 28.05). 


\section{Discussion}

The 2014 European elections saw many Eurosceptic parties across Europe gaining votes, something that was covered by Dutch and Flemish newspapers. The coverage of these elections was characterized by similarities with that of the 2009 elections (Crespy 2011; Vollaard 2011). Just like in 2009, the 2014 elections were more prominent in the Netherlands than they were in Flanders, which was, no doubt, partly due to the co-occurrence of regional and federal elections in Belgium. Likewise, whereas the Flemish newspapers were mostly observing debates elsewhere, the Dutch newspapers also covered a national debate and gave ample space to Eurosceptic voices in that debate: being for or against the EU was a core issue in the debate in the Netherlands. The findings presented here are in line with the general observations made by others that, so far, the EU is still more accepted in Belgium than it is in the Netherlands (Abts et al. 2008), and that the Dutch debate about Europe has mostly taken a for/against nature since the 2005 referendum (de Wilde et al. 2013).

Research has shown that events such as EP elections still draw most attention to the EU, not day-to-day EU affairs. At the same time, they are characterized by a mostly national coverage (de Vreese et al. 2006; Kevin 2003). Studies that have taken a more detailed look at how dayto-day EU affairs feature in the media suggest that these debates often do so too, yet this does depend on the issue at stake (Seifert 2006). Even though European elections would be an ideal opportunity to discuss EU policies, the focus on high profile events results in debates about the nature of integration. The nomination of 'Spitzenkandidaten' by the political groups did not change this - and was even itself discussed, mostly from a purely institutional perspective (see also FitzGibbon et al. 2017: 8). Actors in the debate often were very critical about the EU, regularly representing soft and hard forms of scepticism instead of 'pro-system opposition' (FitzGibbon 2013) or 'constructive criticism' (Statham et al. 2010).

As such the findings presented here suggest that the EU is still far from accepted. However, this would ignore an important point raised before, namely that media coverage of EU affairs may differ between countries, policy fields and institutions. Elsewhere this author used the same approach as that in this chapter to study the occurrences of criticism and opposition to the EU over the period of a year of reporting in three countries. These debates exhibited more claims concerning policy alternatives than just soft or hard Eurosceptic claims (Bijsmans forthcoming 2017b). A similar conclusion followed from a comparison of media reporting of EU affairs in 2009 and 2014 in Britain and the Netherlands - in other words, two years that also included European elections (Bijsmans 2017a). Here too, policy debates mattered, and supportive and Euroalternative claims played an important role.

There is another reason why we need to be careful drawing firm conclusions. During the analysis it became clear that terms like 'Eurocriticism' and 'anti-European' are often used interchangeably - almost randomly even - and, as such, have been coded as hard Eurosceptic statements (unless further specified). The same goes for 'Europhile' and 'pro-European'. One of the readers of NRC Handelsblad even commented on this in a letter: 'Word choice is everything. To me it seems necessary that you [PB: NRC Handelsblad] pick a more precise term for 'anti-Europeans'; this will only benefit the substantive debate about Europe' (NRC 28.05). This issue was also addressed by Financial Times columnist Wolfgang Munchau. In De Telegraaf (19.05) he wrote that the world can no longer be divided in to 'EU-followers' and 'EU-haters'. Instead, the financial crisis has led to the emergence of the 'strayed EU-follower':

Such a strayed EU-follower is not an EU-hater. In their hearts they remain European federalists. In contrast to EU-haters they do not see much in national governments, 


\section{Patrick Bijsmans}

nor in narrowly defined national interests, let alone with waving the national flag. They want a truly federal Europe, but in contrast to the EU fans they no longer believe that the current path is the right one. The strayed EU-follower wants to completely change the whole European project.

The tendency to reduce the debate to a pro- versus anti-Europe discussion may be related to the media's inclination to talk in terms of clear camps. However, it is also illustrative of the more-general fuzziness of these terms and the Dutch debate, in particular, having been framed in terms of for or against the EU since the 2005 referendum.

This does, however, also raise the question how Eurosceptic Euroscepticism actually is, and to what extent the media's attempt to represent European debates truly corresponds with the actual debates. This is a question that cannot be answered here, yet one that warrants further study. As such, Leconte's (2010) suggestion that deficiencies in media reporting may be a source of Euroscepticism is gaining additional importance. The British case, in particular, has shown that the media can play an important role in fuelling myths about European integration (cf. Startin 2015). Reflecting on the recent British vote to leave the EU - in many ways the quintessential example of hard Euroscepticism - it becomes ever more important that we gain a better understanding of, on the one hand, what Euroscepticism entails and, on the other hand, of the relationship between media and Euroscepticism.

\section{Notes}

1 There are no tabloids in Flanders and the Netherlands, hence the inclusion of two popular newspapers.

2 From here on, specific references to newspaper articles will appear as such (abbreviation day.month), where DS stands for De Standaard, HLN for Het Laatste Nieuws, NRC for NRC Handelsblad and TEL for De Telegraaf.

3 All translations from Dutch to English are the author's.

\section{References}

Abts, K., D. Heerwegh and M. Swyngedouw (2008), 'Euroscepticisme in België: Economische belangen, culturele identiteit en politiek wantrouwen', Res Publica, 50(4): 357-381.

Adam, Silke (2009), 'Euroscepticism and the mass media: an analysis of the form of contention in the German and French debates on a European constitution', in Dieter Fuchs, Raul Magni-Berton and Antoine Roger (eds), Euroscepticism: Images of Europe among Mass Publics and Political Elites, Opladen: Barbara Budrich, pp. 193-211.

Beyers, Jan, Hans Vollaard and Patrick Dumont (2015), 'Introduction: European integration and consensus politics', in Hans Vollaard, Jan Beyers and Patrick Dumont (eds), European Integration and Consensus Politics in the Low Countries, London: Routledge, pp. 1-23.

Bijsmans, Patrick (2017a), 'EU media coverage in times of crisis: Euroscepticism becoming mainstream?' in Manuela Caiani and Simona Guerra (eds), Euroscepticism, Democracy and the Media: Communicating Europe, Contesting Europe. Basingstoke: Palgrave Macmillan, pp. 73-94.

Bijsmans, Patrick (forthcoming 2017b), 'Varieties of Euroscepticism and opposition to the EU in the European press', in Simon Usherwood, Nick Startin and Simona Guerra (eds), Euroscepticism in the EU: New Dimensions in Opposition to European Integration, Cheltenham: Edward Elgar.

Boomgaarden, Hajo G., Rens Vliegenthart, Claes H. de Vreese and Andreas R.T. Schuck (2010), 'News on the move: exogenous events and news coverage of the European Union', Journal of European Public Policy, 17(4): 506-526.

Caiani, Manuela and Simona Guerra (eds) (2017), Euroscepticism, Democracy and the Media: Communicating Europe, Contesting Europe, Basingstoke: Palgrave Macmillan.

Crespy, Amandine (2011), 'Europe and Euroscepticism: "Non-issues" in Belgian politics', in Robert Harmsen and Joachim Schild (eds), Debating Europe: The 2009 European Parliament Elections and Beyond, Baden-Baden: Nomos, pp. 17-32. 
Crespy, A. and N. Verschueren (2009), 'From Euroscepticism to resistance to European integration: an interdisciplinary perspective', Perspectives on European Politics and Society, 10(3): 377-393.

Daddow, O. (2012), 'The UK media and "Europe": from permissive consensus to destructive dissent', International Affairs, 88(6): 1219-1236.

de Beus, Jos and Jannette Mak (2009), De kwestie Europa: Hoe de EU tot de Nederlandse Politiek doordringt, Amsterdam: Amsterdam University Press.

Deschouwer, Kris and Martine van Assche (2008), 'Hard but hardly relevant: party-based Euroscepticism in Belgium', in Szczerbiak, Aleks and Paul Taggart (eds), Opposing Europe? The Comparative Party Politics of Euroscepticism. Volume 1: Case Studies and Country Surveys, Oxford: Oxford University Press, pp. 75-92.

de Vreese, C.H. (2007), 'A spiral of Euroscepticism: The media's fault?', Acta Politica, 42(2-3): 271-286.

de Vreese, C.H., S.A. Banducci, H.A. Semetko and H.G. Boomgaarden (2006), 'The news coverage of the 2004 European Parliamentary election campaign in 25 countries', European Union Politics, 7(4): 477-504.

de Wilde, Pieter and M. Zürn (2012), 'Can the politicization of European integration be reversed?', Journal of Common Market Studies, 50(S1): 137-153.

de Wilde, Pieter, Asimina Michailidou and Hans-Jörg Trenz (2013), Contesting Europe: Exploring Euroscepticism in Online Media Coverage, Colchester: ECPR Press.

FitzGibbon, John (2013), "“Another Europe is possible” and the end of Euroscepticism? Addressing the fine-line between opposing Europe and offering a Euro-alternative', Paper presented at the UACES Annual Conference 2013, 2-4 September, Leeds (UK).

FitzGibbon, John, Benjamin Leruth and Nicholas Startin (2017), 'Introduction', in John FitzGibbon, Benjamin Leruth and Nicholas Startin (eds), Euroscepticism as a Transnational and Pan-European Phenomenon: The Emergence of a New Sphere of Opposition, London: Routledge, pp. 1-13.

Guerra, Simona (forthcoming 2017), 'What is Euroscepticism and how do we measure it?' in Simon Usherwood, Nick Startin and Simona Guerra (eds), Euroscepticism in the EU: New Dimensions in Opposition to European Integration, Cheltenham: Edward Elgar.

Hallin, Daniel C. and Paolo Mancini (2004), Comparing Media Systems: Three Models of Media and Politics, Cambridge: Cambridge University Press.

Joris, W., L. d'Haenens and B. van Gorp (2014), 'The euro crisis in metaphors and frames: Focus on the press in the Low Countries', European Journal of Communication, 29(5) 608-617.

Justaert, Arnout (2010), 'Belgium', in Juliet Lodge (ed.), The 2009 Elections to the European Parliament, Basingstoke: Palgrave Macmillan, pp. 52-59.

Karner, C. (2013), 'Europe and the nation: Austrian EU-scepticism and its contestation', Journal of Contemporary European Studies, 21(2): 252-268.

Kevin, D. (2003), Europe in the Media: A Comparison of Reporting, Representation, and Rhetoric in National Media Systems in Europe, Mahwah, NJ: Lawrence Erlbaum Associates.

Kopecký, P. and C. Mudde (2002), 'The two sides of Euroscepticism: party positions on European integration in East Central Europe', European Union Politics, 3(3): 297-326.

Krouwel, A. and K. Abts (2007), 'Varieties of Euroscepticism and populist mobilization: transforming attitudes from mild Euroscepticism to harsh Eurocynicism', Acta Politica, 42(2-3): 252-270.

Leconte, Cécile (2010), Understanding Euroscepticism, Basingstoke: Palgrave Macmillan.

Liebert, Ulrike (2007), 'Transnationalising the public sphere? The European Parliament, promises and anticipations', in John Erik Fossum and Philip Schlesinger (eds), The European Union and the Public Sphere: A Communicative Space in the Making? London: Routledge, pp. 259-278.

Lijphart, Arend (1999), Patterns of Democracy: Government Forms and Performance in Thirty-Six Countries, New Haven, CT: Yale University Press.

Nasra, Skander and Mathieu Seegers (2011), 'Tussen argwaan en pragmatisme: Belgisch-Nederlandse relaties en de Europese integratie, 1949-1969', in Duco Hellema, Rik Coolsaet and Bart Stol (eds), Nederland-België: De Belgisch-Nederlandse Betrekkingen vanaf 1940, Boom: Amsterdam, pp. 109-139.

Risse, Thomas (2010), A Community of Europeans? Transnational Identities and Public Spheres, Ithaca, NY: Cornell University Press.

Rood, Jan and Hendrik Vos (2011), 'Het EU-Beleid van Nederland en België sinds het Einde van de Koude Oorlog', in Duco Hellema, Rik Coolsaet and Bart Stol (eds), Nederland-België: De BelgischNederlandse Betrekkingen vanaf 1940, Boom: Amsterdam, pp. 237-261.

Schout, Adriaan and Jan Rood (2013), 'Europe beyond its image', in Adriaan Schout and Jan Rood (eds), The Netherlands as an EU Member: Awkward or Loyal Partner? The Hague: Eleven International Publishing, pp. 15-30. 


\section{Patrick Bijsmans}

Schuck, Andreas R.T., Rachid Azrout, Hajo Boomgaarden, Matthijs Elenbaas, Joost van Spanje, Rens Vliegenthart and Claes de Vreese (2011), 'Media visibility and framing of the European parliamentary elections 2009: a media content analysis in 27 countries', in Michaela Maier, Jesper Strömbäck and Lynda Lee Kaid (eds), Political Communication in European Parliamentary Elections, Aldershot: Ashgate, pp. 175-196.

Seifert, F. (2006), 'Synchronised national publics as functional equivalent of an integrated European public: The case of biotechnology', European Integration Online Papers, 10(6), available online: http:// eiop.or.at/eiop/pdf/2006-008.pdf (accessed 14 March 2017).

Sifft, S., M. Brüggemann, K. Kleinen von Königslöw, B. Peters and A. Wimmel (2007), 'Segmented Europeanization: exploring the legitimacy of the European Union from a public discourse perspective', Journal of Common Market Studies, 45(1): 127-145.

Sprokkereef, Annemarie (2010), 'The Netherlands', in Juliet Lodge (ed.), The 2009 Elections to the European Parliament, Basingstoke: Palgrave Macmillan, pp. 204-212.

Startin, N. (2015), 'Have we reached a tipping point? The mainstreaming of Euroscepticism in the UK', International Political Science Review, 36(3): 311-323.

Statham, Paul, Ruud Koopmans, Anke Tresch and Julie Firmstone (2010), 'Political party contestation: emerging Euroscepticism or a normalization of Eurocriticism', in Ruud Koopmans and Paul Statham (eds), The Making of a European Public Sphere: Media Discourse and Political Contention, Cambridge: Cambridge University Press, pp. 245-273.

Taggart, Paul and Aleks Szczerbiak (2008), 'Introduction: opposing Europe? The politics of Euroscepticism in Europe', in Aleks Szczerbiak and Paul Taggart (eds), Opposing Europe? The Comparative Party Politics of Euroscepticism. Volume 1: Case Studies and Country Surveys, Oxford: Oxford University Press, pp. 1-15.

Touri, M. and S.L. Rogers (2013), 'Europe's communication deficit and the UK press: framing the Greek financial crisis', Journal of Contemporary European Studies, 21(2): 175-189.

Trenz, H.-J. (2004), 'Media coverage on European governance: exploring the European public sphere in national quality newspapers', European Journal of Communication, 19(3): 291-319.

Usherwood, Simon (2017), 'Modelling transnational and pan-European Euroscepticism', in John FitzGibbon, Benjamin Leruth and Nick Startin (eds), Euroscepticism as a Transnational and Pan-European Phenomenon: The Emergence of a New Sphere of Opposition, London: Routledge, pp. 14-27.

Usherwood, S. and N. Startin (2013), 'Euroscepticism as a persistent phenomenon', Journal of Common Market Studies, 51(1): 1-16.

van Cauwenberge, A., D. Gelders and W. Joris (2009), 'Het Verdrag van Lissabon in het nieuws: Een crossnationale analyse van nieuwsframes in de kwaliteitspers', Res Publica, 51(2): 199-216.

van Holsteyn, Joop and Hans Vollaard (2015), 'Ratifying the European Constitutional Treaty by referendum: The end of consensus politics?' in Hans Vollaard, Jan Beyers and Patrick Dumont (eds), European Integration and Consensus Politics in the Low Countries, London: Routledge, pp. 213-233.

Vasilopoulou, S. (2013), 'Continuity and change in the study of Euroscepticism: plus ça change?', Journal of Common Market Studies, 51(1): 153-168.

Vollaard, Hans (2011), 'Dutch discourses of a small nation in an inefficient Europe: cosmopolitanism, pragmatism, and nationalism', in Robert Harmsen and Joachim Schild (eds), Debating Europe: The 2009 European Parliament Elections and Beyond, Baden-Baden: Nomos, pp. 85-103. 